\title{
PERLINDUNGAN HUKUM TERHADAP KORBAN RANMOR DALAM PERSPEKTIF VIKTIMOLOGI
}

\author{
Imam Akbaru Al Husein, Konsultan Hukum Klinik Utama Rawat Inap Nuraini, Kediri, \\ Indonesia; e-mail: imamakbarualhusein@gmail.com \\ Anik Iftitah, Fakultas Hukum Universitas Islam Blitar, Indonesia; e-mail: \\ geest_willdaad@yahoo.com
}

\begin{abstract}
ABSTRAKSI
Kompleksnya perkembangan kehidupan sosial dapat menimbulkan tingkah laku menyimpang seperti timbulnya tindak pidana pencurian sepeda motor (curanmor). Penelitian yuridis empiris di Kepolisian Resort Nganjuk, Provinsi Jawa Timur menunjukkan bahwa korban curanmor mendapatkan perlindungan berupa restitusi, kompensasi, dan pendampingan. Namun adanya ketidakmemadaian atas sarana prasarana, anggaran, dan kuantitas aparat, terputusnya jaringan informasi, kurangnya alat bukti dan saksi, apatisnya masyarakat, dan kurang memadainya sarana pendukung pada tempat kejadian, menjadi penghampat dalam upaya pencegahan dan perlindungan hukum korban curanmor.
\end{abstract}

\section{PENDAHULUAN}

\section{Latar belakang}

Peran masyarakat dan stakeholder yang terkait dalam pemberlakuan hukum positif di Indonesia, mempengaruhi implementasi produk-produk hukum guna mendapatkan perlindungan hukum dan penerapan asas hukum berkedudukan sama di hadapan hukum/equality before the law yang berlandaskan Pasal 28 D ayat 1 UUD NRI 1945. Ketidakseimbangan antara pelaku dan produk hukum dalam implementasinya, mengakibatkan minimnya sistem keamanan masyarakat terhadap adanya tindak pidana.

Dalam kehidupan sehari-hari lebih khususnya, manusia sering dihadapkan pada suatu kebutuhan yang mendesak, kebutuhan pemuas diri. Bahkan kebutuhan itu timbul karena keinginan atau desakan untuk mempertahankan status diri. Secara umum kebutuhan setiap manusia akan dapat dipenuhi, walaupum tidak seluruhnya. Untuk memenuhi kebutuhan yang mendesak, biasanya sering dilaksanakan tanpa pemikiran matang yang dapat merugikan lingkungan atau manusia lain. Hal seperti itu akan menimbulkan suatu akibat negatif yang tidak seimbang dengan suasana dan kehidupan yang bernilai dengan baik. Untuk mengembalikan kepada suasana dan kehidupan yang bernilai bai, diperlukan suatu pertanggungjawaban dari pelaku yang menciptakan ketidak seimbangan. ${ }^{1}$

Sejalan dengan perkembangan kehidupan sosial yang kompleks, setiap individu ingin merasakan kenikmatan hidup di dunia dengan nyaman. Untuk merasakan kenikmatan bersama yang baik itu batasan-batasan tingkah laku yang mengandung unsur saling menghargai dari masing-masing kepentingan individu dalam situasi kebersamaan dan situasi sosial dapat dirasakan keserasiannya secara bersama. ${ }^{2}$

Kompleksnya perkembangan kehidupan sosial tersebut dapat menimbulkan tingkah laku abnormal atau perilaku menyimpang baik individu atau kelompok. Tingkah laku

\footnotetext{
${ }_{1}^{1}$ Abdoel Djamali, Pengantar Hukum Indnesia, Raja Grafindo Persada, Jakarta, 2010, Hlm 171.

2 Ibid, Hlm 172.
} 
abnormal atau menyimpang adalah tingkah laku yang tidak bisa diterima oleh masyarakat pada umumnya, dan tidak sesuai dengan pribadi yang abnormal itu pada umumnya jauh dari pada status integrasi, baik secara internal dalam batin sendiri, maupun secara eksternal dengan lingkungan sosialnya. ${ }^{3}$

Sebagian besar masyarakat beranggapan bahwa seseorang dianggap menyimpang apabila berperilaku atau bertindak diluar kebiasaan, adat istiadat, aturan, nilai-nilai atau norma yang berlaku. ${ }^{4}$ Perilaku menyimpang dalam masyarakat bermacam-macam, salah satunya tindakan kriminal atau kejahatan. ${ }^{5}$ Kejahatan adalah fenomena yang timbul di kehidupan masyarakat, karena kejahatan juga masalah manusia yang berupa kenyataan sosial. Penyebabnya kurang diketahui, karena dapat saja terjadi dimana dan kapan saja. ${ }^{6}$ Sedangkan naik turunnya angka kejahatan tergantung pada masyarakat, keadaan politik ekonomi, budaya dan sebagainya. ${ }^{7}$

Terjadinya tindak pidana apabila adanya celah dan niat dari pelaku, dalam hal ini menitik beratkan pada kendaraan umum dimana kasus yang mendominasi adalah pencurian khususnya sepeda motor atau disebut curanmor. Pengertian pencurian menurut Pasal 362 Kitab Undang-Undang Hukum Pidana yang selanjutnya disingkat KUHP yaitu, mengambil sesuatu barang milik orang lain dengan cara melawan hukum. Pencurian dalam bentuknya yang pokok (bentuk pencurian biasa) diatur dalam Pasal 362 KUHP Buku II Bab XXII, dalam pasal tersebut memuat batasan dan pengertian pencurian. Tindak pidana pencurian ini memiliki dua bentuk pola pencurian. Dua bentuk pola pencurian tersebut yaitu,yang pertama pencurian dengan pemberatan dan pencurian dengan kekerasan. Pencurian dengan kekerasan diatur dalam Pasal 363 KUHP dan yang kedua pencurian dengan pemberatan diatur dalam Pasal 365 KUHP.

\section{Rumusan masalah}

1. Bagaimana perlindungan hukum korban pencurian sepeda motor ditinjau dari perspektif viktimologi?

2. Bagaimana upaya pencegahan atas terjadinya pencurian sepeda motor di wilayah hukum Polres Nganjuk?

3. Apa hambatan dalam upaya pencegahan atas terjadinya pencurian sepeda motor?

\section{METODE PENELITIAN}

Penelitian yuridis-empiris di Kepolisian Resort Nganjuk (Polres) Nganjuk Kabupaten Nganjuk, Provinsi Jawa Timur ini, menggunakan pendekatan yuridis-sosiologis, untuk mendapatkan data dan informasi mengenai permasalahan tentang perlindungan hukum terhadap korban dalam terjadinya tindak pidana ranmor dalam perspektif viktimologi. Lokasi tersebut menjadi pilihan peneliti sebab presentase tindak pidana pencurian sepeda motor dari setiap semester semakin meningkat.

\footnotetext{
${ }^{3}$ Kartini Kartono, Patologi Sosial Jilid 1 Edisi Baru, Rajawali, Jakarta, 1992, Hlm 13.

4 Syarial Syarbaini dkk, Dasar-dasar Sosiologi, Graha Ilmu, Yogyakarta, 2009, Hlm 83.

${ }^{5}$ Ibid, Hlm 85.

6 Alam A.S, Pengantar Kriminologi,Pustaka Refleksi,Makasar, 2010, Hlm19.

7 Lamintang. P.A.F. Dasar-dasar Hukum Pidana Indonesia, Sinar Baru, Bandung, 1990, Hlm 23.
} 
Jenis data yang digunakan dalam penelitian ini adalah data primer yang langsung diperoleh secara langsung dari objek yang dituju. Dalam kaitannya dengan penelitian ini, peneliti menggunakan data sekunder untuk menelaah secara mendalam terhadap undangundang yang berkaitan dengan tindak pidana pencurian.

Sumber data yang digunakan dalam penelitian ini adalah:

1. Sumber data yang diperoleh dari penelitian lapangan yaitu pihak-pihak responden yang dianggap memiliki relevansi dengan permasalahan yang akan dibahas dan diperoleh melalui proses wawancara.

2. Sumber data yang diperoleh dari kepustakaan yaitu artikel, peraturan perundangundangan yang ada hubungannya dengan objek penelitian.

Data primer diperoleh peneliti melalui wawancara bebas-terpimpin karena data yang sebelumnya disiapkan untuk melakukan wawancara terhadap responden bisa lebih meluas dari apa yang disiapkan sebelumnya, hal tersebut di akibatkan dengan adanya jawaban dari responden secara detail dan meluas. Metode pengumpulan data dengan teknik wawancara dilakukan peneliti dalam hal meminta pandangan dari responden terhadap permasalahan yang telah dirumuskan. ${ }^{8}$

Data sekunder peneliti peroleh melalui penelitian kepustakaan atau menggunakan buku teks yang berisikan mengenai prinsip dasar ilmu hukum dan pandangan-pandangan klasik para sarjana yang mempunyai kualifikasi tinggi yang berhubungan dengan obyek penelitian guna mendapatkan landasan teoritis, dan perundang-undangan yang khususnya mengatur tentang tindak pidana pencurian. ${ }^{9}$

Populasi penelitian ini adalah seluruh pihak yang terkait terhadap perlindungan hukum terhadap korban ranmor dalam perspektif viktimologi di wilayah hukum Polres Nganjuk pada 1 Semester Tahun 2016 (data sekunder 2016), dengan sampel Polres Nganjuk bagian Reserse kriminal pidana umum sebanyak 5 orang dan korban terhadap tindak pidana pencurian sebanyak 5 orang.

Peneliti melakukan penelitian menggunakan teknik sampling purposive yakni sampel tersebut mempunyai tujuan tertentu yang sesuai dengan tema penelitian. Metode analisis data yang digunakan untuk mengolah dan menganalisa data yang telah diperoleh selama penelitian adalah menggunakan metode kualitatif yang dilakukan dengan cara langsung diperoleh dari narasumber tentang data yang dibutuhkan dalam penelitian, kemudian dideskripsikan dan sehingga diperoleh pengertian atau pemahaman, persamaan pendapat maupun perbedaan pendapat dari narasumber mengenai perbandingan bahan hokum primer maupun sekunder dari penelitian yang dilakukan peneliti.

\footnotetext{
${ }^{8} \mathrm{Ibid}, \mathrm{Hlm} 142$.

${ }^{9}$ Ibid.
} 


\section{PERAN KORBAN TERHADAP TINDAK PIDANA RANMOR}

\section{Perkembangan Tindak Pidana Pencurian Kendaraan Bermotor Roda Dua di Kabupaten Nganjuk}

Persoalan tindak pidana pencurian kendaraan bermotor adalah salah satu permasalahan yang sering terjadi dikehidupan masyarakat manapun, tidak terkecuali di Kabupaten Nganjuk dengan berbagai dinamika dan persoalan sosial masyarakatnya.

Kepolisian Negara Republik Indonesia ( Polri ) dalam hal ini ditugaskan oleh negara sebagai penyidik tunggal terhadap tindak pidana umum, hal ini berlandaskan hukum pada pasal 6 (1) KUHP sub a, bahwa penyidik adalah Pejabat Polisi republik Indonesia. ${ }^{10}$

Tindak pidana umum dalam hal ini pencurian kendaraan bermotor roda dua merupakan kejahatan terhadap harta benda yang memberikan hasil cukup bernilai ekonomi bagi para pelaku. ${ }^{11}$ Tindak pidana pencurian kendaraan bermotor roda dua adalah salah satu bentuk kajahatan yang sering terjadi dan sangat meresahkan masyarakat, kerugian yang dialami korban pun bisa dibilang tidak sedikit. ${ }^{12}$ Untuk menggambarkan jumlah tindak pidana pencurian kendaraan bermotor tersebut, peneliti menunjukkannya di dalam tabel yang didasarkan atas laporan masuk yang di tangani kepada Polres Nganjuk dimana data tersebut sudah di rekapitulasi oleh pihak Polres guna proses penyidikan. Adapun tabel tersebut adalah:

Tabel Kasus Ranmor yang Ditangani Pada 1 Semester

\begin{tabular}{|l|c|c|}
\hline No & Bulan & Jumlah \\
\hline 1. & Mei & 3 \\
\hline 2. & Juni & 2 \\
\hline 3. & Juli & 2 \\
\hline 4. & Agustus & 3 \\
\hline
\end{tabular}

Sumber: Data Sekunder Polres Nganjuk Tahun 2016, Diolah Tahun 2017

\section{Peranan Korban Dalam Tindak Pidana Ranmor}

${ }^{10}$ Muladi dan Barda Nawawi Arief, Teori-Teori dan Kebijakan Pidana, Alumni, Bandung, 2005, Hlm 43.

${ }^{11}$ Sudarto, Hukum Pidana I, Yayasan Sudarto Fakultas Hukum UNDIP, Semarang, 1990, Hlm 32.

12 Wirjono Prodjodikoro, Tindak-Tindak Pidana Tertentu di Indonesia, Refika Aditama, Bandung, 2012, Hlm 14. 
Berbicara mengenai viktimologis akan erat kaitannya dengan pembicaraan bagaimanakah peranan korban dalam terjadinya suatu tindak pidana, termasuk salah satunya pada kasus pencurian kendaraan bermotor roda dua.

Menurut Aipda Awaluddin selaku penyidik dan Kepala Urusan Administrasi (Kaurmin) Polres Nganjuk yang berdasarkan wawancara menjelaskan secara terperinci mengenai peranan korban dalam terjadinya tindak pidana pencurian kendaraan bermotor, dimana faktor kelalaian menjadi penyebab utamanya menempati urutan teratas dengan persentase $65 \%$, lalu diikuti oleh karena adanya hubungan famili ataupun pertemanan dengan pelaku20\% dan faktor kurangnya tingkat pendidikan atau pendidikan yang rendah menjadi faktor terakhir dengan $15 \% .{ }^{13}$

Tabel Korban dalam Ranmor dalam 1 semester

\begin{tabular}{|l|c|c|}
\hline No & Peran Korban Dalam Ranmor & Presentase \\
\hline 1. & Kelalaian & $65 \%$ \\
\hline 2. & Hubungan Keluarga / Teman & $20 \%$ \\
\hline 3. & Tingkat Pendidikan Rendah & $15 \%$ \\
\hline & Jumlah & $100 \%$ \\
\hline
\end{tabular}

Sumber: Data Primer 2017

Menurut Aipda Awaluddin, faktor kelalaian pemilik kendaraan menjadi penyebab utama terjadinya tindak pidana pencurian kendaraan bermotor roda dua di Kabupaten Nganjuk. Hal ini disebabkan karena pemilik kendaraan bermotor kurang berhati-hati, sehingga dapat memancing seseorang melakukan suatu tindak pidana, khususnya pencurian kendaraan bermotor roda dua. Dari kelalaian pemilik kendaraan bermotor tersebut timbullah kesempatan bagi seseorang untuk melakukan tindak pidana pencurian kendaraan bermotor roda dua khususnya di Kabupaten Nganjuk. ${ }^{14}$

Kemudian faktor kedua yaitu hubungan keluarga atau teman. Menurut Aipda Awaluddin, hubungan keluarga atau pertemanan menjadi faktor selanjutnya dimana seseorang dapat menjadi korban pencurian kendaraan bemotor roda dua dengan mudah. Karena adanya kepercayaan yang tinggi terhadap keluarga atau teman menyebabkan seseorang terkadang tidak menyadari bahwa hal tersebut bisa saja menjadi penyebab dirinya menjadi korban. ${ }^{15}$ Masih berkaitan dengan faktor kedua yang dikemukakan oleh Aipda Awaluddin, peneliti kemudian melakukan wawancara dengan seseorang yang pernah menjadi korban. (Ibnu, 20 tahun ). Ibnu

${ }^{13}$ Hasil wawancara dengan Aipda Awaludin, Anggota Satreskrim, 19 Februari 2017.

${ }^{14} \mathrm{Idem}$.

${ }^{15}$ Idem. 
pernah meminjamkan motornya kepada salah seorang teman dekatnya. Tanpa sepengetahuan Yaser, temannya tersebut menggandakan kunci kontak motornya. Setelah motornya dikembalikan Yaser tidak menyadari bahwa kunci kontaknya telah digandakan sampai beberapa waktu kemudian motornya hilang. ${ }^{16}$ Setelah Kasus tersebut dilaporkan dan diselidiki, kemudian motor Ibnu tersebut dapat ditemukan dan pelakunya tertangkap. Pelakunya memang bukanlah teman Ibnu yang meminjam motornya, namun setelah pihak kepolisian melakukan penyelidikan lebih mendalam terhadap pelaku, ternyata kemudian diketahui bahwa pelaku melakukan aksinya karena memiliki kunci duplikat motor tersebut. Pelaku bekerja sama dengan teman korban. Kasus ini menunjukkan bahwa adanya hubungan keluarga atau teman tidak menjamin seseorang akan aman dari tindak pidana pencurian kendaraan bermotor atau tidak menjadi korban.

Faktor ketiga seseorang dapat menjadi korban penipuan yaitu, kurangnya tingkat pendidikan ataupun tingkat pendidikan yang rendah. Faktor terakhir menurut Aipda Awaluddin adalah karena kurangnya pemahaman seseorang terhadap suatu tindak pidana dan ataupun kurangnya kepekakaan terhadap apa yang sedang dialaminya memudahkan seseorang untuk menjadi korban tindak pidana pencurian kendaraan bermotor roda dua. Tetapi tidak jarang juga banyak ditemukan kasus pencurian kendaraan bermotor roda dua dimana korbannya adalah orang-orang yang memiliki tingkat pendidikan tinggi, sambut Aipda Awaluddin. ${ }^{17}$

Tingkat pendidikan rendah adalah salah satu faktor peranan yang diberikan seseorang untuk menjadi korban pencurian kendaraan bermotor roda dua, namun dengan persentase yang tidak lebih besar jika dibandingkan faktor pertama dan kedua.

Kemudian bagaimana dengan kondisi disekitar lingkungan tempat tinggal dan jenis kelamin korban? Lebih lanjut Aipda Mujinah menyatakan bahwa faktor lingkungan tempat tinggal atau rumah dan jenis kelamin tidaklah menjadi faktor penentu dimana seseorang itu dapat menjadi korban pencurian kendaraan bermotor, mengingat derajat kesalahan seorang korban pencurian kendaraan bermotor lebih kepada apa yang dalam dirinya seperti lalai dalam memarkir kendaraan bukan dengan apa yang ada disekitar lingkungan tempat tinggalnya ${ }^{18}$.

Terkait apakah jenis kelamin juga salah satu bentuk peran yang diberikan korban dalam terlaksananya suatu kasus pencurian kendaraan bermotor, maka peneliti

\footnotetext{
${ }^{16} \mathrm{Idem}$.

17 Idem.

${ }^{18}$ Hasil Wawancara dengan Aipda Mujinah anggota Satreskrim tanggal 19 Februari 2017.
} 
mencoba menguraikan jumlah korban pencurian kendaraan bermotor selama empat tahun terakhir berdasarkan jenis kelamin yaitu, sebagai berikut; 19

Tabel Jumlah Korban Ranmor Berdasakran Jenis Kelamin dari Laporan Yang Masuk di Wilayah Hukum Polres Nganjuk

\begin{tabular}{|c|c|c|c|c|}
\hline \multirow{2}{*}{ No } & \multirow{2}{*}{ Bulan } & \multicolumn{2}{|c|}{ Jenis Kelamin } & \multirow{2}{*}{ Jumlah } \\
\cline { 3 - 4 } & & Laki- Laki & Perempuan & \\
\hline 1. & Mei & 4 & 3 & 7 \\
\hline 2. & Juni & 3 & 2 & 5 \\
\hline 3. & Juli & 5 & 2 & 7 \\
\hline 4. & Agustus & 1 & 2 & 3 \\
\hline & & Jumlah & 22 \\
\hline
\end{tabular}

Sumber: Data Sekunder, Diolah Tahun 2017

Untuk menjawab mengenai peranan korban dalam terjadinya suatu tindak pidana ranmor, lebih lanjut peneliti melakukan wawancara dengan salah satu korban pencurian kendaraan bermotor roda dua yaitu Muhammad fauzi (23 tahun) yang menjadi korban karena kelalaiannya sendiri. Karena terburu-buru dia tidak sempat memarkir motornya dengan baik dengan anggapan bahwa ia hanya sebentar saja masuk ke dalam rumah untuk mengambil sesuatu. Ternyata setelah ia keluar rumah dalam rentan waktu hanya 15 menit motornya hilang. Pelaku sangat cepat dan lihai dalam melakukan aksinya. ${ }^{20}$

Lebih lanjut lagi peneliti melakukan wawancara dengan salah satu korban ranmor warga yaitu Nurul Hikmah (21 tahun). Waktu itu malam hari korban hendak tidur, dan seperti biasa ia memarkir motornya di halaman rumah dan menguncinya dengan menggunakan kunci ganda, dengan anggapan bahwa hal tersebut sudah cukup aman bagi motornya. Namun apa yang terjadi ketika ia bangun keesokan harinya, ternyata motornya sudah tidak ada. ${ }^{21}$

Setelah peneliti melakukan wawancara dengan banyak korban, sebagian besar dari mereka yang kehilangan kendaraan bermotor miliknya tidak menemukan kembali kendaraan mereka. Kenyataan ini sangat memprihatinkan karena kendaraan bermotor ruda dua bukanlah barang yang memiliki nilai ekonomi rendah. Lebih memprihatinkan lagi karena sebagian besar korban yang peneliti wawancarai merupakan golongan masyarakat yang berada pada tingkat ekonomi menengah ke

19 Idem.

${ }^{20}$ Wawancara dengan korban ranmor atas nama M. Fauzi tanggal 19 Februari 2017.

21 Wawancara dengan korban ranmor atas nama Nurul Hikmah tanggal 19 Februari 2017. 
bawah. Mereka mengandalkan kendaraan bermotor roda dua sebagai alat penunjang utama dalam pekerjaan mereka.

\section{BENTUK PERLINDUNGAN HUKUM BAGI KORBAN RANMOR}

Perlindungan hukum dalam hal ini erat kaitannya dengan hak-hak korban, dan langkah perlindungan yang diberikan lebih bersifat reaktif daripada proaktif. Dikatakan reaktif karena langkah ini ditujukan kepada mereka yang telah mengalami atau menjadi korban kejahatan dan melaporkannya kepada pihak yang berwajib untuk diproses lebih lanjut. Namun, yang menjadi permasalahannya adalah bahwasanya sering kali korban memutuskan untuk tidak melaporkan akan adanya suatu kejahatan yang menimpa mereka. ${ }^{22}$

Terlepas daripada faktor-faktor tersebut, dalam UU No. 8 Tahun 1981 tentang KUHAP secara tegas telah diatur bentuk perlindungan hukum ini, demikian pula dalam UU No. 5 Tahun 1991 tentang Kejaksaan, Pasal 27 ayat (1) huruf (a) yang merumuskan bahwa kejaksaan bertugas melakukan penuntutan dalam perkara pidana, meskpipun dalam menjalankan tugasnya untuk dan atas nama negara, akan tetapi juga mewakili korban tidak pidana. Selain itu, di dalam deklarasi PBB tentang Declaration of Basic Principles of Justice for Victims of Crimes and Abuse of Power pada tahun 1985, telah dirumuskan bentuk perlindungan yang dapat diberikan kepada korban yaitu:23

1) Access to justice and fair treatment.

2) Restitution.

3) Compensation.

4) Assistance.

Korban kejahatan pada umumnya tertuju pada manusia yang mempunyai hak dan kewajiban serta menuntut perlakuan yang sama dengan orang lain, termasuk perlakuan terhadap pelaku kejahatan. Jaminan perlakuan terhadap korban seringkali dituntut, karena merupakan salah satu bentuk perlindungan. Upaya penegakkan hukum tidak akan membawa hasil manakala tidak diimbagi dengan perasaan keadilan, termasuk didalamnya rasa keadilan para korban kejahatan. ${ }^{24}$

Oleh karenanya setiap sub-sistem dalam sistem peradilan pidana senantiasa memiliki tanggung jawab berupa tanggung jawab hukum untuk menegakkan hukum negara dan tanggung jawab moral untuk mlindungi, memulihkan dan menjunjung

${ }^{22}$ Kartini Kartono, Patologi Sosial Jilid I Edisi Baru, Rajawali, Jakarta, 1992, Hlm 51.

${ }^{23}$ Deklarasi PBB, tentang Declaration of Basic Principles of Justice for Victims of Crimes and Abuse of Power, diakses tanggal 19 Februari 2017.

${ }^{24}$ M. Yahya Harahap, Pembahasan Permasalahan dan Penerapan KUHAP Penyidikan dan Penuntutan, Sinar Grafika, Jakarta 2005, Hlm 42. 
tinggi harkat martabat manusia. Apabila terjadi penyimpangan terhadap kedua tanggung jawab di atas maka akan menimbulkan efek negatif terhadap tersangka maupun korban. ${ }^{25}$

Sedangkan berbicara mengenai hak-hak korban, terdapat hak kompensasi dan restitusi sebagaimana juga disebutkan di dalam Declaration of Basic Principles of Justice for Victims of Crimes and Abuse of Power pada tahun 1985, dimana berdasarkan deklarasi ini hak-hak korban secara umum adalah mendapatkan:26

1. Restitusi

2. Kompensasi

3. Pendampingan

\section{UPAYA PENCEGAHAN TINDAK PIDANA RANMOR}

Upaya-upaya yang dilakukan untuk menaggulangi terjadinya ranmor yakni melalui upaya preventif, preemtif dan upaya represif.

Upaya preemtif adalah upaya yang dilakukan sebelum terjadinya tindak pidana atau lebih tepatnya sebagai upaya pencegahan dari suatu tindak pidana. Upaya ini merupakan tindakan yang dilakukan secara sistematik, berencana, terpadu, dan terarah kepada tujuan untuk menciptakan suasana yang kondusif guna menekan terjadinya tindak pidana pencurian kendaraan bermotor roda dua di wilayah hukum Polres Nganjuk. Berdasarkan hasil wawancara Aipda Awaluddin mengatakan bahwa upaya-upaya yang dilakukan untuk mencegah terjadinya tindak pidana pencurian kendaraan bermotor adalah: 27

1. Dengan bantuan tim BINMAS ( Bina Mitra Masyarakat) yang terdapat disetiap kelurahan guna memberikan pengetahuan melalui penyuluhan hukum terhadap hal-hal yang harus dilakukan agar terhindar dari berbagai tindak pidana termasuk pencurian kendaraan bermotor. Kegiatan ini melibatkan seluruh masyarakat dan tokoh-tokoh masyarakat. Penyuluhan ini dilaksanakan pada sekolah-sekolah dan tempat-tempat umum dalam rangka memberikan pengetahuan kepada masyarakat agar tidak menjadi korban dalam tindak pidana pencurian kendaraan bermotor.

2. Melalui sosialisasi ataupun pemberitaan melalui berbagai media baik itu visual ataupun cetak dalam bentuk iklan layanan sosial ataupun himbauan yang terpasang diberbagai ruas jalan.

${ }^{25}$ Prasetyo, Tegus. Sari Hukum Acara Pidana 1 A, Mitra Prasaja, Yogyakarta, 2002, Hlm 67. ${ }^{26}$ Ninik Widiyanti, yulius waskita, Kejahatan dalam masyarakat dan pencegahannya, Bina Aksara, Jakarta, 1987, Hlm 53

${ }^{27}$ Hasil Wawancara dengan Aipda Awaludin, Anggota Satreskrim, diolah tanggal 19 februari 2017 
Upaya preventif berikutnya adalah melalui koordinasi dengan lembaga pemerintah dan nonpemerintah serta pihak lain dalam rangka penegakan undangundang, disamping itu dilakukan kerjasama dengan lembaga-lembaga sosial.

Menurut Aipda Awaluddin upaya-upaya diatas sudah cukup efektif. Tindakantindakan diatas paling tidak dapat memberikan pengertian tentang berbagai tindak pidana dan memberikan pemahaman kepada setiap warga masyarakat untuk lebih waspada dikarenakan setiap orang mempunyai potensi untuk menjadi korban tindak pidana. Selain itu upaya-upaya diatas juga memberikan pemahaman kepada masyarakat bahwa setiap perbuatan tindak pidana mempunyai sanksi tegas kepada setiap pelakunya. Jadi tidak hanya menghimbau masyrakat untuk berhati-hati tetapi upaya-upaya diatas juga mengajak masyarakat untuk bertindak sesuai dengan aturan dan norma-norma yang berlaku. ${ }^{28}$

Upaya lainnya yaitu, upaya represif. Upaya represif merupakan tindakantindakan yang dilakukan pihak kepolisian setelah tindak pidana tersebut terjadi. Upaya represif baru diterapkan apabila upaya lain sudah tidak memadai atau efektif lagi untu mengatasi suatu tindak pidana. ${ }^{29}$

Lebih lanjut Aipda Awaluddin menyatakan bahwa upaya represif dilakukan dengan menindak lanjuti setiap laporan tindak pidana termasuk tindak pidana pencurian kendaraan bermotor. Kemudian memberikan sanksi hukum yang tegas terhadap pelaku tindak pidana, guna memberikan efek jera, sesuai dengan rasa keadilan didalam masyarakat dan kepastian hukum. Selain itu, mengadakan pemeriksaan terhadap tersangka dan barang bukti seta upaya hukum lainnya dalam rangka penyidikan perkara pencurian kendaraan bermotor roda dua di wilayah hukum Polres Nganjuk, dan selanjutnya jika sudah lengkap (P-21) segera dilimpahkan ke kejaksaan. ${ }^{30}$

\section{HAMBATAN DALAM UPAYA PENCEGAHAN RANMOR}

\section{Kendala Internal}

1). Sarana dan prasarana kurang memadai

2). Jaringan informasi yang terputus

3) Kurang memadainya anggota kepolisian dari segi kuantitas

4) Kurang dukungan anggaran

Rincian pengunaan dukungan anggaran untuk satreskrim sebagai berikut :

Tabel Rincian Dukungan Dana untuk Satreskrim Tahun 2016

28 Ibid.

29 Ibid.

30 Ibid. 


\begin{tabular}{|l|l|l|}
\hline No & \multicolumn{1}{|c|}{ Program } & \multicolumn{1}{c|}{ Jumlah Anggaran } \\
\hline 1. & Penyelidikan dan Penyidikan T.P & Rp. 661.020.000,00 \\
\hline 2. & Biaya Adm. Ops Lidik Sidik & Rp. $14.300 .000,00$ \\
\hline 3. & Kegiatan Identifikasi Kepolisian & Rp. $16.400 .000,00$ \\
\hline 4. & Bantek Lidik Sidik & Rp. 6.000.000,00 \\
\hline
\end{tabular}

Sumber : Data Sekunder Dana untuk Satreskrim, Diolah Tahun 2017

Berdasarkan rincian anggaran tersebut, untuk program penyelidikan dan penyidikan tindak pidana dibagi lagi menjadi 3 ( tiga ) kategori berdasarkan tingkat kesulitan kasusnya, yaitu kasus mudah, kasus sedang dan kasus sulit. Berikut adalah rincian penggunaan dana untuk penyelidikan dan penyidikan tindak pidana berdasarkan tingkat kesulitan kasusnya :

Tabel Rincian Penggunaan Dana untuk Penyelidikan dan Penyidikan Tindak Pidana Berdasarkan Tingkat Kesulitan

\begin{tabular}{|l|c|l|}
\hline No & Tingkat Kesulitan Kasus & \multicolumn{1}{|c|}{ Jumlah Anggaran } \\
\hline 1. & Mudah & Rp. 156.420.000,00 (per 33 kasus) \\
\hline 2. & Sedang & Rp. 325.500.000,00 (per 35 kasus) \\
\hline 3. & Sulit & Rp. 179.100.000,00 (per 12 kasus) \\
\hline
\end{tabular}

Sumber : Data sekunder rincian penggunaan dana Satreskrim, diolah tahun 2017

\section{Kendala Eksternal}

1) Kurangnya alat bukti dan saksi

2) Masyarakat yang apatis dalam membantu pihak kepolisian

\section{PENUTUP}

Bentuk perlindungan korban terhadap tindak pidana ranmor dalam prespektif viktimologi oleh pihak yang berwenang dalam pemenuhan hak-hak korban adalah melalui tindakan restitusi, kompensasi, dan pendampingan, dengan upaya pencegahan ranmor berupa :

a. Upaya Preemtif

Upaya yang dilakukan dengan cara pendekatan kepada masyarakat dengan cara sebagai berikut :

a) Adanya pembentukan Binmas (Bina Mitra Masyarakat) yang berfungsi untuk memberikan sosialisasi secara langsung, betapa pentingnya menjaga barang pribadi terhadap adanya tindak pidana yang ada di sekitar masyarakat.

b) Melalui sosialisasi ataupun pemberitaan melalui berbagai media baik itu visual ataupun cetak dalam bentuk iklan layanan sosial ataupun himbauan yang terpasang diberbagai ruas jalan

b. Upaya Preventif 
Tindakan yang ditujukan untuk mencegah secara langsung terjadinya kejahatan dengan cara pemberian pemahanan kepada masyarakat terhadap pentingnya undang - undang dalam mengayomi masyarakat dari adanya kejahatan terutama pada ranmor.

c. Upaya Represif

Upaya terakhir yang dilakukan dengan cara melakukan sanksi hukum yang berlaku setelah upaya represif telah di berlakukan.

3. Hambatan dalam upaya pencegahan ranmor

Dalam upaya melakukan pencegahan ranmor sudah banyak dilakukan oleh pihak kepolisian, namun adanya hambatan dalam pencegahan tersebut juga timbul. Bentuk hambatan yang timbul dalam upaya pencegahan ranmor adalah sebagai berikut :

a. Hambatan Internal berupa :

a) Sarana dan prasarana kurang memadai.

b) Jaringan informasi yang terputus.

c) Kurang memadainya aparat dari segi kuantitas.

d) Kurang dukungan anggaran.

b. Hambatan Eksternal berupa :

a) Kurangnya alat bukti dan saksi.

b) Masyarakat yang apatis dalam membantu pihak kepolisian.

c) Sarana pendukung pada tempat kejadian perkara kurang memadai.

Cara meminimalisir tindak pidana ranmor, yakni sebagai berikut :

1. Meminta bantuan satuan lalu lintas apabila terjadi hambatan di lapangan yang notabene nya bertugas untuk penegakan hukum di bidang lalu lintas.

2. Membangun jaringan informasi, baik dari jajaran polsek maupun masyarakat yang lebih baik sehingga dalam penyidikan khususnya ranmor menjadi maksimal.

3. Menambah jam dinas yang sebelumnya telah diberlakukan, sehingga anggota kepolisian segera dapat menindaklanjuti tindak pidana ranmor.

Peran serta masyarakat dalam pencegahan ranmor, antara lain:

1. Sebisa mungkin untuk memasang kamera CCTV yang berkualitas, paling tidak terpasang pada jalan-jalan yang dianggap rawan dan sepi agar memudahkan penyidik untuk mendapatkan petunjuk khususnya dalam kasus ranmor.

2. Mulai merubah pemikiran bahwa ranmor merupakan tindak pidana yang dilakukan karena adanya kesempatan. Karena pada dasarnya ranmor cenderung pada pada tindak pidana yang telah direncanakan dan untuk hal itu diharapkan kepada masyarakat untuk tidak apatis dan peduli dalam menekankan pencegahan adanya tindak pidana khususnya ranmor. 
3. Diharapkan korban memberikan alat pengamanan tambahan agar tidak terjadi ranmor, seperti alarm, kunci ganda, navigasi. Apabila menjadi korban telah menjadi korban ranmor, sebisa mungkin untuk langsung melakukan laporan kepada pihak kepolisian supaya ditindaklanjuti oleh kepolisian.

\section{DAFTAR PUSTAKA}

Alam. A.S, Pengantar Kriminologi, Pustaka Refleksi, Makassar, 2010.

Anwar H.A.K, Muhammad, Hukum Pidana Bagian Khusus, Citra Aditya Bhakti, Bandung, 1989.

Anwar, Moch, Hukum Pidana Bagian Khusus (KUHP Buku II) Jilid I, Alumni, Bandung, 1986.

Bemmelen, J.M. van, Hukum Pidana 1 Hukum Pidana Material Bagian Umum, Binacipta, Bandung, 1987.

Chazawi, Adami, Kejahatan Terhadap Harta Benda, Bayu Media, Malang, 2003.

Djamali, Abdoel, Pengantar Hukum Indonesia, Raja Grafindo Persada, Jakarta, 2010.

Gosita, Arief, Masalah Korban Kejahatan Kumpulan Karangan, Akademika Pressindo, Jakarta, 1993.

Hamzah, Andi, Azas-Azas Hukum Pidana Edisi Revisi, Rineka Cipta, Jakarta, 2010.

Harahap, M. Yahya, Pembahasan Permasalahan dan Penerapan KUHAP Penyidikan dan Penuntutan, Sinar Grafika, Jakarta, 2005.

Hartono, Penyidikan dan Penegakan Hukum Pidana melalui Pendekatan Hukum Progresif, Sinar Grafika, Jakarta, 2012.

Huda, Chairul, Dari " Tiada Pidana Tanpa Kesalahan" menuju kepada "Tiada Pertanggungjawaban Tanpa Kesalahan" Tinjauan Kritis Terhadap Teori Pemisahan Tindak Pidana dan Pertanggungjawaban Pidana, Kencana, Jakarta, 2006.

Ilyas, Amir, Asas - Asas Hukum Pidana edisi revisi, Rangkang Education, Makasar, 2012.

Kartono, Kartini, Patologi Sosial Jilid I Edisi Baru, Rajawali, Jakarta, 1992.

Lamintang. P.A.F, Dasar-dasar Hukum Pidana Indonesia, Sinar Baru, Bandung, 1990.

Marzuki, Peter Mamud, Penelitian Hukum, Kencana Prenada Media Group, Jakarta, 2005

Muladi, dan Arief, Barda Nawawi Teori-Teori dan Kebijakan Pidana, Alumni Bandung, 2005.

Prasetyo, Tegus, Sari Hukum Acara Pidana 1 A, Mitra Prasaja, Yogyakarta, 2002

Prastyo, Teguh, Hukum Pidana Edisi Revisi, PT. Raja Grafindo Persada, Jakarta, 2011

Sahetapy, J.E., Bungai Rampai Viktimisasi, Eresco, Bandung, 1995.

Santoso, Topo, Kriminologi, Rajawali, Jakarta,2009.

Soerbakti, Eka S. Lorena, Membela Angkutan Umum, Penerbit Buku Kompas, Jakarta, 2015.

Sudarto, Hukum Pidana I, Yayasan Sudarto Fakultas Hukum UNDIP, Semarang, 1990.

Syarbaini, Syahrial dkk, Dasar-dasar Sosiologi, Graha Ilmu, Yogyakarta, 2009. 
Tim Penyusun Kamus Pusat Pembinaan dan Pengembangan Bahasa, Kamus Besar Bahasa Indonesia, , Departemen Pendidikan dan Kebudayaan Republik Indonesia, 1988.

Widiyanti, Ninik; Waskita, Yulius, Kejahatan dalam Masyarakat dan Pencegahannya, Bina Aksara, Jakarta, 1987.

Yulia, Rena, Viktimologi Perlindungan Hukum Terhadap Korban Kejahatan, Graha Ilmu, Yogyakarta, 2010.

UNDANG - UNDANG:

Undang-Undang Dasar Negara Republik Indonesia 1945.

Kitab Undang-Undang Hukum Pidana.

Undang-Undang Nomor 8 Tahun 1981 Tentang KUHAP.

Undang-Undang Nomor 5 Tahun1991 Tentang Kejaksaan.

Undang-Undang Nomor 18 Tahun 1997 Tentang Pajak Daerah dan Retribusi Parkir. Undang-Undang Nomor 2 Tahun 2002 Tentang Kepolisian.

Undang-Undang Nomor 22 Tahun 2009 Tentang Lalu Lintas dan Angkutan Jalan.

Peraturan Daerah Nomor 3 Tahun 2008 Tentang Pengelolaan Parkir.

Internet:

Bangsa online, penadah motor curian diringkus timsus-nganjuk, diakses 03 Agustus 2016.

Mabes Polri, Profil, Tugas dan Fungsi Polri (Online) (12 Januari 2017)

Jurnal. Deklarasi PBB, tentang Declaration of Basic Principles of Justice for Victims of Crimes and Abuse of Power, diakses tanggal 19 Februari 2017. 